This is a self-archived version of an original article. This version may differ from the original in pagination and typographic details.

Author(s): Tynjälä, Päivi

Title: Pedagogical Perspectives in Higher Education Research

Year: 2017

Version:

Copyright: @ Springer Science+Business Media Dordrecht 2017

Rights: In Copyright

Rights url: http://rightsstatements.org/page/lnC/1.0/?language=en

Please cite the original version:

Tynjälä, P. (2017). Pedagogical Perspectives in Higher Education Research. In P. Teixeira, \& J. Shin (Eds.), Encyclopedia of International Higher Education Systems and Institutions (pp. 1-6). Springer Netherlands. https://doi.org/10.1007/978-94-017-9553-1_170-1 


\section{Pedagogical Perspectives in Higher Education Research}

\section{Synonyms}

Studies on teaching and learning in higher education; Research on learning and instruction in higher education; Research on student learning in university; Research on teaching in university

\section{Definition}

Research focusing on teaching and learning in universities

\section{Cross references}

E-learning in higher education; Learning outcomes, higher education; Students' experiences in higher education; Governance of teaching and learning in higher education; Linking innovation, education and research; Transformative learning, higher education

Higher education pedagogy is a fairly young research field, stemming from early research during the 1970s and growing widely since the 1990s. The following sections present firstly main research lines focusing on student learning and secondly those examining teaching and teachers.

\section{Studies on student learning}

In research on student learning in higher education, it has been typical to make a distinction between the typically European/Australian tradition of focusing on student approaches to learning and the more American tradition of self-regulation studies. In addition, there is a growing research line of research on learning patterns, which aims to bridge these two traditions to form a more holistic perspective on student learning.

Research on student approaches to learning started to expand during the 1970s, when Marton and Säljö (1979) identified the two, now well-known approaches, that is, the surface approach and the deep approach. Typical to the surface approach is students' rote learning in order to pass 
exams, whereas in the deep approach students foremost seek a better understanding of the topic being studied. In addition to these two basic approaches to learning, a third approach referred to as the achieving approach or strategic approach or organized studying was identified in several studies (see, e.g. Entwistle and McCune, 2004). Typical to this approach is that the student fundamentally aims for high grades and organises his or her studies in a way that maximises the possibility of good achievement. Research has shown that while some students tend to approach their studying in a similar way and independent of their learning environment, other students vary in their learning approach in different learning environments (e.g., Lindblom-Ylänne et al., 2004). Thus, existing research suggests that student approaches to learning are dynamic and that it is possible to influence them through pedagogical arrangements.

Although the topic of student approaches to learning has been a widely examined research area, students' approaches form only one part of the complex phenomenon of student learning. A more comprehensive perspective has been provided by Biggs (1999) with the 3P Model of Learning. The three Ps form the basic components of learning seen as a holistic phenomenon: Presage, Process, and Product. The presage factors that predict learning processes and products include, first, student-related factors, such as prior knowledge and motivation; and, second, factors related to teaching contexts, such as teaching methods and assessments. The process component pertains to students' activities when learning and their learning approaches. The product part of the model refers to learning outcomes such as knowledge, skills and attitudes. More recently, Price (2014) added a fourth 'P' to the model, Perceptions, representing students' and teachers' conceptions of learning and their perceptions of the context. The fourth ' $\mathrm{P}$ ' thus indicates that the influence of presage factors on the learning process is usually indirect, that is, through how students perceive these factors. For example, if a student finds his or her own skills inadequate, he/she may not put enough effort into learning; or, when students perceive the learning environment as requiring rote learning they may adaptively adopt a surface approach.

The 3P and 4P Models of Learning have been widely used as a theoretical framework in research into student learning in higher education. Recent studies have focused, for example, on the relationship between students' perceptions of their learning environment (presage factor), their learning approaches (process factor), and their actual study success (product factor). In general, 
studies have found a positive relationship between the deep approach and study success, but there are also exceptions indicating that when teachers emphasise rote learning it is possible to achieve high grades with a surface approach as well. Usually, organised studying has related positively to study success. Students' perception of their learning environment seems to have an indirect effect on their study success via approaches to learning. This means that when students perceive their teaching-learning environment as interesting and relevant, they are more likely to adopt a deep approach to learning and achieve high grades.

Some recent studies have examined whether there are differences between disciplines in how students approach their learning and how they perceive their learning environment, and differences have indeed been found. For example, in a study by Parpala et al. (2011), students of Veterinary Medicine scored significantly higher than students in other faculties with respect to four factors measuring perceptions of teaching-learning environments: teaching for understanding, alignment, interest and relevance, and support from other students. In the same study, law students had the lowest or second lowest scores for all of these factors. That study is just one example, but other studies have confirmed that there are disciplinary differences in how students perceive their learning environment at university and how they approach their studies.

As a parallel research tradition to research on student approaches to learning, studies on selfregulated learning in higher education have produced a rich knowledge base of how students engage in their studies. The concept of self-regulation refers to processes by which students monitor and control their thinking and activities during the learning process in order to achieve their (self-set) learning goals. A widely used model of self-regulation by Pintrich and Zusho (2007) shows a similarity with the 3P Model by Biggs (1999), although the model stems from a different theoretical framework. According to their model, personal characteristics such as age and gender, as well as classroom context characteristics such as academic tasks and instructional methods, influence motivational as well as self-regulatory processes, both of which have an impact on outcomes. According to extensive research, in general, self-regulated students, that is, students who set their own goals and plan, monitor and reflect on their motivation and study process, are more likely to succeed in their studies than those students who lack these kinds of regulation strategies. 
In addition to research on student approaches to learning and self-regulation of learning, there is a third line of research that has conceptualised broader learning patterns, that is, combinations of learning conceptions, approaches, and ways of regulating learning. This research line aims to unify studies on cognitive strategies, regulation strategies, motivation and learning conceptions (Vermunt and Donche, 2017). Like Biggs' 3P Model and the model by Pintrich and Zusho (2007), the model of learning patterns by Vermunt and Donche (2017) acknowledges the influence of personal and contextual factors on students' learning conceptions, motivation, regulation strategies and processing strategies, and their influence on learning outcomes.

Four qualitatively different learning patterns have been identified in research (e.g., Lonka et al., 2004): 1) Reproduction-directed learning, where the student has a traditional 'intake of knowledge' view of learning and aims to memorise what is to be learnt in order to be able to reproduce it in an exam. These students are usually highly dependent on external regulation by teachers. 2) Meaning-directed learning, which refers to the internally motivated and selfregulated attempt to understand learning materials. These students see learning as a constructive rather than reproductive process. 3) Application-directed learning, in which students try to make links between learning at the academy and in the outside world. Thus, they value usable knowledge and are oriented towards their future vocation. 4) Undirected learning, referring to the lack of regulation, and an ambivalent learning orientation. In general, meaning-oriented learning is positively associated to successful learning outcomes, whereas undirected learning is negatively associated to them (Vermunt and Donche, 2017).

Generic skills as learning outcomes in university

In recent decades, learning outcomes have received more and more attention in higher education. One example is the feasibility study Assessment of Higher Education Learning Outcomes (AHELO) by the Organisation for Economic Co-operation and Development (OECD), which experimented with measuring both domain-specific learning outcomes and generic skills across cultures (Tremblay et al., 2012). Recently, the OECD has agreed to partner with an American institute measuring learning outcomes, the Council for Aid to Education (CAE), concerning a 
new initiative to assess learning outcomes in higher education on a global scale. This initiative will use the CAE's Collegiate Learning Assessment (CLA+), an assessment tool that measures generic skills using a performance-based instrument (a similar tool that was used in AHELO).

At the same time, research literature has paid more and more attention to the development of generic skills, also referred to with other terms, such as transferable skills, generic attributes, key skills, $21^{\text {st }}$ century skills, or core competencies. Research on generic skills in higher education has produced, first, several definitions and lists of generic skills. These vary but they commonly include communication skills (e.g., oral presentation and academic writing), thinking skills (e.g., problem solving and critical thinking), and interpersonal skills (e.g., teamwork and collaboration). Second, many studies have focused on how university graduates perceive the contributions that their university education has made to their development of these skills. Third, there are studies that have aimed to identify mechanisms through which universities pursue developing generic skills. The findings suggest that active, collaborative learning, linking theory and practice, and diversified assessment methods are all important for the development of generic skills.

\section{Teachers' Pedagogical Methods and Approaches to Teaching}

Along with the research on student learning, another broad research field focuses on university teachers and their teaching. These studies focus on university teachers' conceptions of learning and teaching, their approaches to teaching, and specific teaching paradigms and methods. One widely used tool for measuring teachers' approaches to teaching is the Approaches to Teaching Inventory (ATI-R) (Trigwell and Prosser, 2004). The inventory measures two main approaches to teaching, namely, the Conceptual Change or Student-focused (CCSF) approach and the Information Transmission or Teacher-focused (ITTF) approach. In the former, teachers take students' prior knowledge into account in their teaching and support their active learning, whereas the latter focuses on the transmission of knowledge involving little interaction with students. Some studies have shown that sometimes teachers' intentions and actual teaching strategies may be inconsistent and that the same teacher may alter his or her approach to teaching in different contexts (Lindblom-Ylänne et al., 2006). Teachers also differ in their conceptions of 
their own growth and development as teachers. In her phenomenographic study, Åkerlind (2003) found three ways of how teachers described their development: Changes in the teacher (increasing comfort and confidence, decreasing effort in teaching), changes in the teaching practice (increasing skills and knowledge), and changes in the outcomes for learners (increasing student learning).

Research on university teaching naturally covers a wide range of studies on different pedagogical approaches such as the constructivist approach to teaching and learning, and regarding specific curricular solutions and methods such as problem-based learning (PBL), project-based learning, inquiry-based learning, team-based learning, flipped classroom, work-related learning, and service learning. Common to these approaches is that they all represent student-centred learning emphasising students' active role in the learning process. Studies related to different pedagogical and curricular solutions have focused, for example, on students' and teachers' experiences of new forms of studying, the emotional dimension in learning, student approaches to learning, and learning outcomes. Recently, the use of technology and new study opportunities, such as MOOCs (Massive Open Online Courses), have also received more and more attention. These studies have revealed both advantages and challenges in the use of technology in higher education. An important but so far seldom researched topic related to such technological applications is the regulation of learning, especially in collaborative contexts (Järvelä et al., 2016). A general conclusion of studies on the role of technology in learning could be formulated as it not being the technology itself that matters but rather the pedagogical solutions that support students' learning processes.

While the bulk of pedagogical research in higher education is confined to classroom learning, there is a growing research field focusing on learning taking place outside the classroom. Because of rapid changes in society and the economy, there is a need to enhance both employees' opportunities for continuous learning and students' opportunities to experience authentic work during their studies. In the United Kingdom and Australia, for example, a new form of educational practice, work-based learning partnerships, has been established. In this form of education, employees are enrolled as students and complete a study programme for formal qualifications but remain based at their workplace (e.g., Boud, 2006). In Finland, 
universities of applied sciences offer similar Master's degree level programmes for people who have gained at least three years of work experience since completing their Bachelor's degree level studies. Usually, students in these programmes are employed and conduct a development project at their workplace as part of their studies. In another similar example from a German university, fully employed people may take a program on Business Administration which is based on action learning (solving realistic complex problems), networking (working with a network consisting of lecturers, mentors, experts and participants), and work-based learning (work experience as an integral part of the program) (Hartmann et al., 2009).

At the same time, with work-based study programmes for employees having been established in many countries, the integration of work experience in study programmes for higher education students in general has also become more common (e.g., Billett, 2015; Tynjälä and Gijbels, 2012). Studies on students' work placements, practicum, apprenticeship, internship, project assignments and other forms of learning based on authentic work experience at or in collaboration with a workplace have focused not only on students' personal experiences but also on the influence of work on graduate employability. According to most studies, the availability of various work experience opportunities and/or working alongside one's higher education studies enhances students' employability and actual employment.

When the context of learning is not only a classroom, but is rather being built on the basis of a combination of experiences in different contexts such as the workplace, school, Internet, and leisure activities, new kinds of pedagogy are needed for guiding and supporting students' learning process. The model of Integrative Pedagogy (e.g. Tynjälä \& Gijbels, 2012; Tynjälä et al., 2016) is one example of pedagogical tools designed for this purpose. According to the Integrative Pedagogy model, it is important that theoretical knowledge learned at university and practical knowledge gained in a work placement and in other contexts should not remain separate but be tightly integrated and fused with each other in order to develop a high level of expertise. For connecting different forms of knowledge, students are assigned learning tasks in which they need to apply theoretical knowledge to practical assignments and reflect on their practical experiences in the light of theory with the help of conceptual knowledge. The model has been applied in different disciplines, and it has proven itself to be a fully functional tool for supporting 
learning both in the classroom context and for connecting school learning with workplace learning. Technological tools and software have also been developed to support student reflection in linking theoretical and practical knowledge.

In sum, pedagogical research in higher education has evolved from its narrowly focused emergence through early research studies in the 1970s to being a broad, diversified research field. Among this field's most well-known research lines are student learning on the one hand and teaching approaches on the other. There are also studies that combine these two by examining, for example, the relationships between student factors, learning environment factors, and factors related to learning outcomes. Another broad research area is made up of studies on a variety of pedagogical approaches, methods and tools. A third, fast-growing line of research is

forming from studies focusing on integrating of academic learning and workplace learning, while a fourth new major field focuses on the role of technology in learning.

\section{References}

Åkerlind, Gerlise, S. 2003. Growing and developing as a university teacher: Variation in meaning. Studies in Higher Education 28: 375-90.

Biggs, John. 1999. Teaching for quality learning at university: What the student does. Buckhingham: Society for Research into Higher Education \& Open University Press.

Billett, Stephen. 2015. Integrating practice-based experiences into higher education. Dordrecht: Springer.

Boud, David and Nicky Solomon, eds. 2001. Work-based learning: A new higher education? Buckingham: Society for Research into Higher Education \& Open University Press. 
Entwistle, Noel and Velda McCune. 2004. The conceptual basis of study strategy inventories. Educational Research Review 16: 325-345.

Hartmann, Ernst, A., Michaela Knust, Claudia Loroff, and Ida Stamm-Riemer, 2009. Towards permeability between vocational education and academic education. Experiences and analysis from current initiatives in Germany. European Journal of Education 44: 352-368.

Järvelä, Sanna, Paul A. Kirschner, Allyson Hadwin, Hanna Järvenoja, and Jonna Malberg. 2016. Socially shared regulation of learning in CSCL: Understanding and prompting individual- and group-level shared regulatory activities. International Journal of Computer-Supported Collaborative Learning 11, 263-280.

Lindblom-Ylänne, Sari, Anna Parpala, and Liisa Postareff. 2004. Challenges in analyzing change in students' approaches to learning. In Learning Patterns in Higher Education, ed. David Gijbels, Vincent Donche, John T. E. Richardson, and Jan D. Vermunt, 232-248. London: Routledge.

Lonka, Kirsti, Erkki Olkinuora, and Jarkko Mäkinen. 2004. Aspects and prospects of measuring studying and learning in higher education. Educational Psychology Review 16: 301-323.

Marton, Ference and Roger Säljö. 1976. On qualitative differences in learning: I. Outcome and process. British Journal of Educational Psychology 46: 4-11.

Pintrich, Paul, R. and Akane Zusho. 2007. Motivation and self-regulated learning in the college classroom. In Handbook on teaching and learning in higher education, ed. R. Perry and J. Smart, 731-810. Dordrecht: Springer.

Postareff, Liisa, Sari Lindblom-Ylänne, and Anne Nevgi. 2008. A follow-up study of the effect of pedagogical training on teaching in higher education. Higher Education 56: 29-43. 
Price, Linda. 2014. Modelling factors predicting student learning outcomes in higher education. In Learning patterns in higher education: Dimensions and research perspectives, ed. David Gijbels, Vincent Donche, John T. E. Richarson, and Jan D. Vermunt, 56-77. London: Routledge.

Tremblay, Karine, Diane Lalancette, and Deborah Roseveare. 2012. AHELO. Feasibility study report. Volume 1. OECD. http://www.oecd.org/edu/skills-beyond$\underline{\text { school/testingstudentanduniversityperformancegloballyoecdsahelo.htm }}$

Trigwell, Keith and Michael Prosser. 2004. Development and use of the Approaches to Teaching Inventory. Educational Psychology Review 16: 409-425.

Tynjälä, Päivi. \& Gijbels, David. (2012). Changing world - changing pedagogy. In Transitions and transformations in learning and education, ed. Päivi Tynjälä, Marja-Leena Stenström and Marjatta Saarnivaara, 205-222. Dordrecht: Springer.

Tynjälä, Päivi, Anne Virtanen, Ulla Klemola, Emma Kostiainen, and Helena Rasku-Puttonen. 2016. Developing social competence and other generic skills in teacher education: Applying the model of integrative pedagogy. European Journal of Teacher Education, published online April 15, 2016, http://www.tandfonline.com/eprint/fMZhjvwHME36As6NuwdC/full.

Vermunt, Jan and Vincent Donche. 2017. A learning patterns perspective on student learning in higher education: State of the art and moving forward. Educational Psychology Review 29: 269299. 